\title{
Hydrogeology of the Alluvial Aquifers at the Pueblo Depot Activity Near Pueblo, Colorado
}

\author{
by Daniel T. Chafin
}

U.S. GEOLOGICAL SURVEY

Water-Resources Investigations Report 95-4137

Prepared in cooperation with the

U.S. ARMY CORPS OF ENGINEERS and the

U.S. ARMY PUEBLO DEPOT ACTIVITY

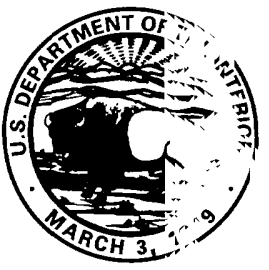




\section{U.S. DEPARTMENT OF THE INTERIOR BRUCE BABBITT, Secretary}

U.S. GEOLOGICAL SURVEY

Gordon P. Eaton, Director

The use of trade, product, industry, or firm names is for descriptive purposes only and does not imply endorsement by the U.S. Government.

For additional information write to:

Copies of this report can be purchased from:

District Chief

U.S. Geological Survey

Box 25046, MS 415

Denver Federal Center

Denver, CO 80225
U.S. Geological Survey

Earth Science Information Center

Open-File Reports Section

Box 25286, MS 517

Denver Federal Center

Denver, CO 80225 


\section{CONTENTS}

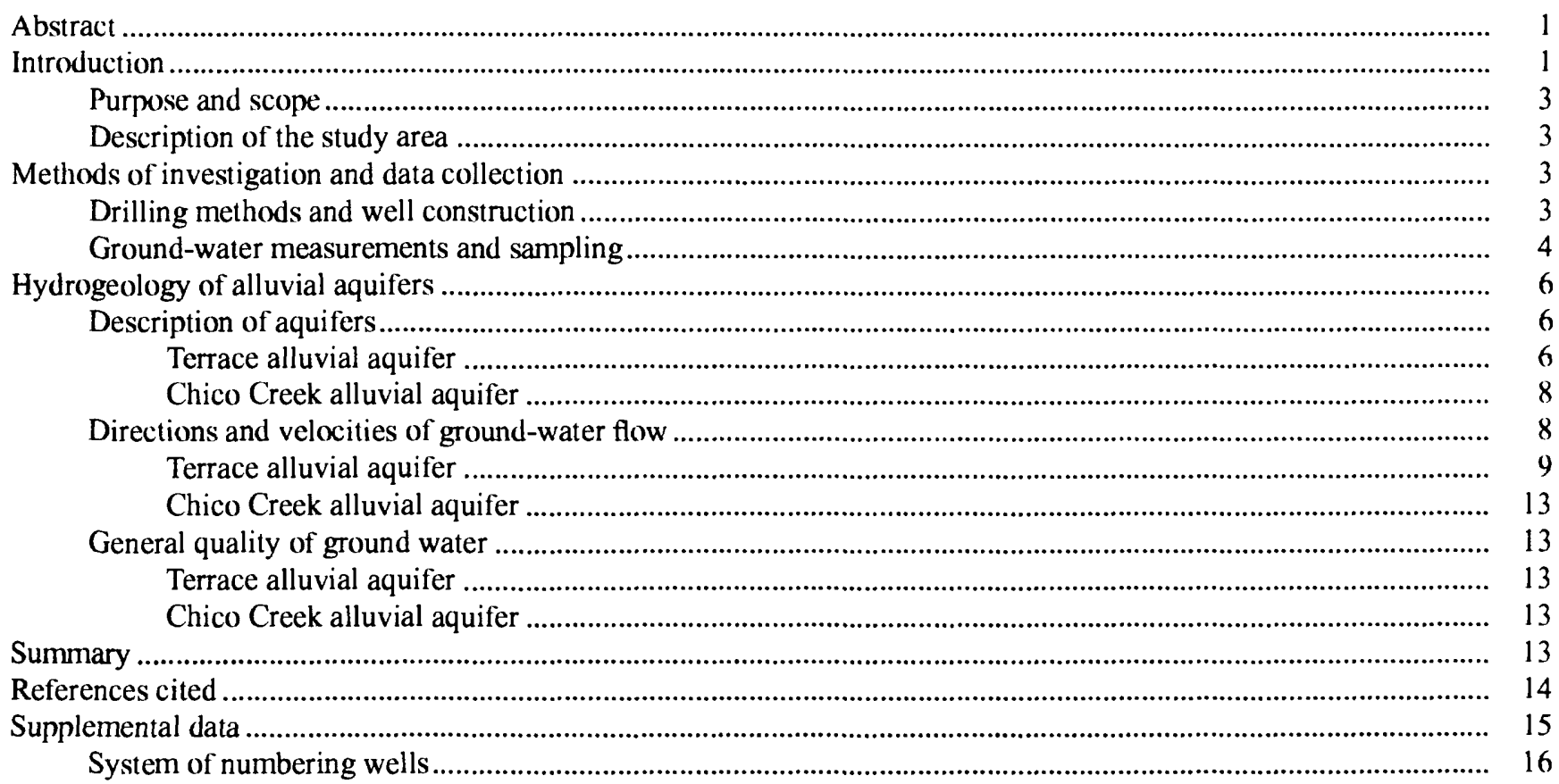

\section{PLATES}

[In-pocket]

1-4. Maps showing:

1. Altitude of the Pierre Shale of Upper Cretaceous age underlying the alluvial aquifers at the Pueblo Depot Activity near Pueblo, Colorado

2. Saturated thickness of the alluvial aquifers at the Pueblo Depot Activity near Pueblo, Colorado, June and July 1993

3. Altitude of the water table in the alluvial aquifers at the Pueblo Depot Activity near Pueblo, Colorado, June and July 1993

4. Specific conductance of ground water in the alluvial aquifers at the Pueblo Depot Activity near Pueblo, Colorado, June and July 1993

\section{FIGURES}

1. Map showing location of the Pueblo Depot Activity

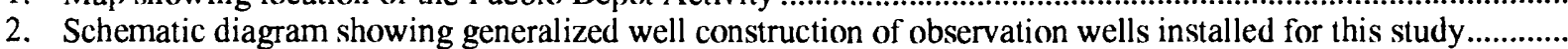

3. Generalized hydrogeologic section showing relation between terrace alluvial aquifer and Chico Creek alluvial aquifer

4. Map showing values of hydraulic conductivity of the alluvial aquifers at the Pueblo Depot Activity

\section{TABLES}

1. Values of hydraulic conductivity of the alluvial aquifers at the Pueblo Depot Activity...

2. Construction data for observation wells installed for this study

3. Drillers' logs for observation wells and test holes drilled for this study .....

4. Onsite measurements and concentrations of selected major inorganic constituents in samples collected from observation wells installed for this study and selected preexisting wells, June 1993 
CONVERSION FACTORS, VERTICAL DATUM, AND ABBREVIATIONS

\begin{tabular}{rcl} 
Multiply & By & To obtain \\
\hline & & \\
acre-foot per day (acre-ft/d) & 1,233 & cubic meter per day \\
cubic foot per day $\left(\mathrm{ft}^{3} / \mathrm{d}\right)$ & 0.0283 & cubic meter per day \\
foot $(\mathrm{ft})$ & 0.3048 & meter \\
foot per day $(\mathrm{ft} / \mathrm{d})$ & 0.3048 & meter per day \\
foot per mile $(\mathrm{ft} / \mathrm{mi})$ & 18.94 & centimeter per kilometer \\
inch (in.) & 2.54 & centimeter \\
inch per year (in/yr) & 2.54 & kilometer per year \\
mile $(\mathrm{mi})$ & 1.609 & square kilometer \\
square mile $\left(\mathrm{mi}^{2}\right)$ & 2.59 & \\
\hline
\end{tabular}

Degree Celsius $\left({ }^{\circ} \mathrm{C}\right)$ may be converted to degree Fahrenheit $\left({ }^{\circ} \mathrm{F}\right)$ by using the following equation:

$$
{ }^{\circ} \mathrm{F}=9 / 5\left({ }^{\circ} \mathrm{C}\right)+32 \text {. }
$$

Other abbreviations, terms, and symbols used in this report:

micrometer $(\mu \mathrm{m})$

microsiemens per centimeter at 25 degrees Celsius $(\mu \mathrm{S} / \mathrm{cm})$

milligram per liter $(\mathrm{mg} / \mathrm{L})$

Sea level: In this report "sea level" refers to the National Geodetic Vertical Datum of 1929 (NGVD of 1929)--a geodetic datun derived from a general adjustment of the first-order level nets of both the United States and Canada, formerly called Sea Level Datum of 1929. 


\title{
Hydrogeology of the Alluvial Aquifers at the Pueblo Depot Activity Near Pueblo, Colorado
}

\author{
By Daniel T. Chafin
}

\section{Abstract}

In 1992, the U.S. Army Corps of Engineers and the U.S. Army Pueblo Depot Activity requested that the U.S. Geological Survey study the hydrogeology of the Pueblo Depot Activity, a 36-square-mile facility that has been operated by the U.S. Army since 1942. The purpose of the study was to provide an updated hydrogeological framework to facilitate the investigation of specific sites on the facility that might require remediation. This report describes the hydrogeology of the alluvial aquifers beneath the facility and the distribution of specific conductance of ground water in those aquifers.

The Pueblo Depot Activity is underlain by two alluvial aquifers: (1) The terrace alluvial aquifer, which is a southernmost, downgradient part of an erosional remnant of an extensive terrace deposit; and (2) the Chico Creek alluvial aquifer, a smaller alluvial system along Chico Creek. These aquifers primarily consist of sand separated by clay layers and are underlain by the almost impermeable Pierre Shale of Upper Cretaccous age.

The bedrock surface, which has an average slope of 28 feet per mile to the south-southeast, is relatively regular beneath the northern twothirds of the terrace deposits at the Pueblo Depot Activity, but forms an irregular surface of troughs, hills, and ridges in the southwestern part of the terrace alluvium. Saturated thickness of the terrace aquifer ranges from 0 to about 45 feet.

The bedrock surface beneath the Chico Creek aquifer slopes about 31 feet per mile to the south. Saturated thickness of the Chico Creek alluvium ranges from 0 to about $30 \mathrm{ft}$, but generally is less than $15 \mathrm{ft}$. Total thickness of the Chico Creek alluvium in the saturated area ranges from 16 to $41 \mathrm{ft}$.

Water in the terrace alluvial aquifer generally flows southward, except in the southwestern part where directions of flow are complex. Meas- ured hydraulic conductivity ranges from 0.4 to 400 feet per day (median 26 feet per day). Estimates for vertically averaged ground-water-flow velocity range from 0.02 to 3 feet per day (median 0.9 foot per day).

Water in the Chico Creek alluvial aquifer generally flows southward to the Arkansas River alluvium. Measured hydraulic conductivity ranges from 14 to 310 feet per day (median 42 feet per day). Estimates for vertically averaged ground-water-flow velocity range from 0.5 to 4 feet per day (median 0.7 foot per day).

Specific conductance of ground water in the terrace alluvial aquifer generally is less than 800 microsiemens per centimeter; the smallest values were observed in the north-central part of the Pueblo Depot Activity. In the southw'estern part of the terrace alluvial aquifer, values varied in an irregular pattern, and values as large as 3,300 microsiemens per centimeter were measured locally. Water in the terrace alluvial aquifer was dominated by the sodium cation and usually by the bicarbonate anion, and sulfate usually was present in substantial (and locally predominant) concentrations.

Measured specific conductance of water in the Chico Creek alluvial aquifer ranged from 683 to 1,460 microsiemens per centimeter. This water was dominated by the sodium cation and by the bicarbonate and sulfate anions; sulfate was more predominant to the south.

\section{INTRODUCTION}

The Pueblo Depot Activity (PUDA) is a $36-\mathrm{mi}^{2}$ facility that has been operated by the U.S. Army since 1942. The PUDA is located adjacent to the Arkansas River Valley about $10 \mathrm{mi}$ east of Pueblo, Colorado (fig. 1). The PUDA is required by the 1976 Resource Conservation and Recovery Act and related leg slation and Executive orders to comply with Federal, S tate, and local regulations that require prevention, control, 
and remediation of environmental pollution. Previous and ongoing investigations by private contractors have identified a number of sites on the facility that have contaminated or might have contaminated the shallow alluvial aquifers underlying the facility. These investigations have utilized a preliminary study of the hydrogeology of the PUDA conducted by the U.S. Geological Survey (USGS) (Welder and Hurr, 1971). Since the publication of that report, additional hydrogeologic data have been acquired. In 1992, the USGS, at the request of the U.S. Army Corps of Engineers and the U.S. Army Pueblo Depot Activity, began a study designed to use this additional data to more fully characterize the hydrogeology of the alluvial aquifers beneath the PUDA. Tho specific objectives of this study were to define:

1. The extent, potentiometric surface, saturated thickness, and hydraulic conductivity of the alluvial aquifers;

2. The regional and local ground-water-flow paths in the alluvial aquifers; and

3. The distribution of specific conductance (or dissolved solids) and a description of water types in the alluvial aquifers.
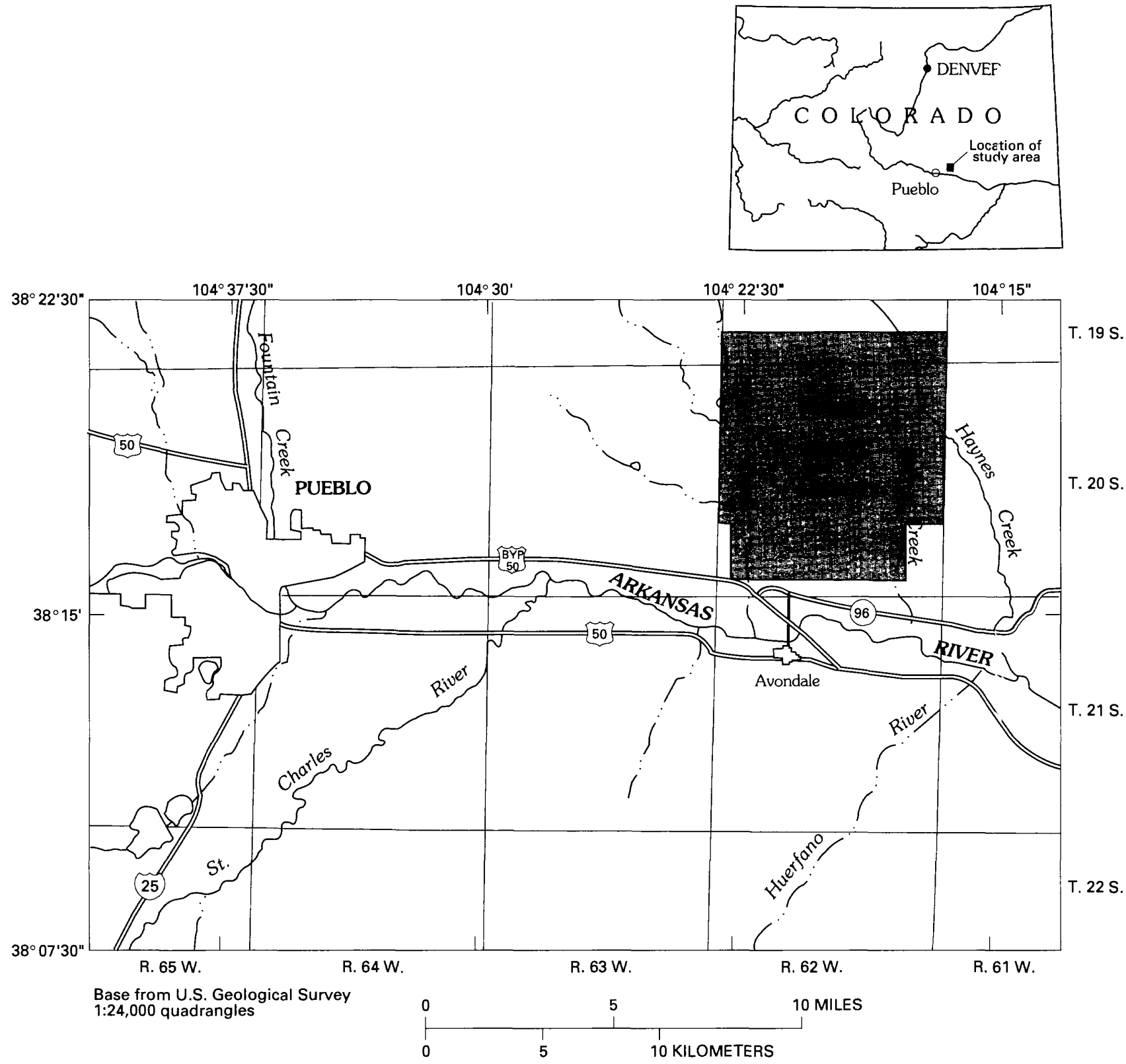

Figure 1. Location of the Pueblo Depot Activity. 


\section{Purpose and Scope}

This report describes the hydrogeology of the alluvial aquifers beneath the PUDA and the distribution of specific conductance of ground water in those aquifers. The descriptions are based on a compilation of data from additional well installations and studies by private contractors, nine observation wells and four test holes installed for this study, and ground-water measurements made mostly during 1993. Maps depict the spatial variation of hydrogeologic characteristics and specific conductance of ground water in the alluvial aquifers.

\section{Description of the Study Area}

Most of the PUDA is on a terrace in the western part of the Colorado Piedmont section of the Great Plains physiographic province. The topography is broadly rolling, having steep scarps at the edges of the terrace; ephemeral creeks and ditches have incised the terrace. The surface altitude of the terrace ranges from about $4,810 \mathrm{ft}$ at the northern boundary of the PUDA to about $4,650 \mathrm{ft}$ at the southern boundary along a distance of about $6 \mathrm{mi}$, resulting in an average slope of about $27 \mathrm{ft} / \mathrm{mi}$. The southern edge of the terrace is about $150 \mathrm{ft}$ above the adjacent Arkansas River Valley.

The climate of the study area is semiarid; mean annual precipitation is about $11 \mathrm{in}$. (Watts and Ortiz, 1990). Precipitation generally occurs as rain between May and September and snow between November and March. Mean lake evaporation is $48 \mathrm{in} / \mathrm{yr}$ at the PUDA (U.S. Army Corps of Engineers, written commun., 1988). Because potential evaporation greatly exceeds precipitation, the potential for recharge to the terrace alluvial aquifer beneath the PUDA is small. Most of the study area is covered with grass; however, brush and cacti exist locally, especially on the extreme northwestern and northeastern parts of the PUDA. Trees and brush are clustered in arroyos.

The PUDA is drained by Chico Creek on the west, Boone Creek on the southeast, and Haynes Creek on the east (fig. 1). These creeks flow southward to the Arkansas River Valley. Chico Creek is perennial north of a point about $2.5 \mathrm{mi}$ upstream from its intersection with the Arkansas River Valley and usually flows during the winter south of this point. Boone Creek is headed by a perennial spring, the discharge of which disappears into colluvium and alluvium within a short distance; Boone Creek usually flows only in response to rainfall runoff or snowmelt. Haynes Creek is intermittent, but usually flows during the winter.
The administrative area of the PUDA is located near the southern boundary of the facility (pl. 1), is about $1.5 \mathrm{mi}^{2}$ in area, and contains numerous buildings amidst trees. An intensive network of roads in the north-central and central parts of the facility are lined with ammunition-storage bunkers built during World War II. Additional small clusters of bui 'dings are scattered throughout the PUDA.

\section{METHODS OF INVESTIGATION AND DATA COLLECTION}

Hydrogeologic data used in this study consist of water-level altitudes, drillers' logs, and hydraulic conductivities. Most of these data were obtained from preexisting wells, such as water-supply wells drilled for the PUDA, several stock wells, observation wells and test holes drilled for previous USGS studies (W'elder and Hurr, 1971; Watts and Ortiz, 1990), and numerous observation wells drilled by private contractors for the U.S. Army Corps of Engineers. In addition, nine observation wells and four test holes were drilled for this study in areas for which data were sparse. Altitude surveys were conducted for wells for which measuringpoint altitudes were unavailable.

Water-level measurements were made in numerous preexisting and in all newly installed wells. and water samples were collected for temperature, specific conductance, and $\mathrm{pH}$. Laboratory analyses for selected constituents were undertaken on samples from the nine wells installed for this study and from four precxisting wells.

After field data were collected for this stıdy, additional hydrogeologic data became availabls as a result of installation of additional observation wells and drilling of additional boreholes by private contractors. These data were used to more fully chara-terize the configurations of the bedrock surface and water table and the distribution of saturated thickness

\section{Drilling Methods and Well Construction}

Nine observation wells and four test holes were drilled for this study during January and February 1993. Well name, station number, loral well number, land-surface altitudes, measuring-point (top of casing) stick-up heights, and depths to the top and bottom of screened intervals of observation wells are listed in table 2. Drillers' logs describing tho lithology for the observation wells and test holes are listed in table 3; both of these tables are in the "Supplemental Data" section at the back of the report. Locations of wells and test holes are shown on plate 1. 
All holes were drilled to bedrock (Pierre Shale of Upper Cretaceous age) using an 8-in hollow-stem auger that had a 3.25-in inside diameter. Where alluvium was present and saturated, casing was installed to form an observation well. Where alluvium was absent or unsaturated, the drill holes were backfilled with earth materials; these drill holes were designated as test holes.

All wells were constructed using schedule- 40 , polyvinyl chloride (PVC) casing that had a 2-in inside diameter (fig. 2). Well screens consisted of machineslotted PVC casing with a 2 -in inside diameter and a 0.010 -in slot width. Screen varied from 4 to $20 \mathrm{ft}$ in length, depending on the saturated thickness of the alluvial aquifer. A $0.4-\mathrm{ft}$ pointed PVC cap was placed at the bottom end of the screen section. All casing components were threaded and flush-jointed, needing no solvent or cement for assembly.

Five observation wells were constructed so that the screen bottoms were near bedrock; however, four wells were installed so that the screen bottoms were substantially above bedrock. After emplacement of casing strings, a silica sand pack was emplaced at least $2 \mathrm{ft}$ above the top of the screen for six wells; the formations were allowed to collapse around the screens of three wells (ATMW-01, CAMW-01, and CAMW-02) because heaving formation sands made emplacement of silica sand unfeasible. After emplacement of the sand pack or collapse of the formation, a minimum of $2 \mathrm{ft}$ of bentonite pellets was emplaced above the sand pack or collapsed formation. After these pellets had hydrated, a cementbentonite grout seal was slurried above them to within $2 \mathrm{ft}$ of the land surface. A 5-ft-long steel protective casing that had a locking cap was set over the PVC casing and into the center of a 3 -ft by 3 - $\mathrm{ft}$ by 6 -in-thick concrete pad. Three 4-in-diameter steel posts were cemented in place around each well to protect it against accidental destruction. Prior to sampling, each well was developed by pumping twice, using an air-lift pump, until sediment was no longer visible in the discharge.

\section{Ground-Water Measurements and Sampling}

During June and July 1993, 23 observation wells, 6 water-supply wells, 4 stock wells, and 1 spring were measured for water levels and sampled for measurements of temperature, specific conductance, and $\mathrm{pH}$. Thirteen of the sampled observation wells were installed by the USGS in the 1960's (Welder and Hurr, 1971) using galvanized steel pipe that had an inside diameter of 1.25 in.; prior to sampling, the wells were tested for suitability for sampling and, if suitable (not missing, plugged, collapsed, or bent), bailed using a 5-ft PVC bailer that had a 0.75 -in inside diameter until three or more casing volumes of water (the volume of water initially in the casing) were removed.

Water levels in the observation wells were measured before sampling using steel or electric tapes. Water levels in active water-supply well were not measured because the casings were sealed for sanitary protection. Water levels in two windmill-driven stock wells were measured when they were nct being pumped.

All wells (except one) that were sampled for water-quality measurements were either purged three or more casing volumes immediately before sampling (all observation wells) or had been pumped immediately before sampling (six water-supply wells, two stock wells, and one household well). ( 1 e stock well that had a 28 -in-diameter casing could not be purged economically with available equipment. Observation wells that had 1.25 -in casings were purged using a bailer. Observation wells that had 2-in casings were purged using an air-lift pump or a bladder pump or both. All 2-in wells were purged of at least one of the three or more casing volumes with the bladder pump used for sampling. Temperature, specific conductance, and $\mathrm{pH}$ were measured immediately after purging.

The nine observation wells installed for this study, two preexisting observation wells, and two water-supply wells were sampled for on cite measurements of temperature, specific conductance, $\mathrm{pH}$, and alkalinity and for laboratory analyses of major ions (calcium, magnesium, sodium, potassium, sulfate, and chloride), fluoride, silica, nitrite plu nitrate, and dissolved-solids residue (at $180^{\circ} \mathrm{C}$ ). The samples to be analyzed for these constituents were filtered through a $0.45-\mu \mathrm{m}$ cellulose acetate filter. The $\mathrm{s}^{\wedge m p l e s}$ for analysis of calcium, magnesium, sodium, potassium, and silica were stabilized using nitric ac:d. The samples for analysis of nitrite plus nitrate were stabilized using mercuric chloride. Results of onsite measurements and laboratory analyses for these 13 wells are listed in table 4 in the "Supplemental Data" section.

Water levels were measured at 74 additional sites where water-quality measurements were not made for this study. These sites consisted of 72 onservation wells, 1 inactive water-supply well, and 1 abandoned household well. These water levels were used to help map saturated thickness (pl. 2) and altitude of the water table (pl. 3) in the alluvial aquifers.

Bail tests were done to determine hydraulic conductivity for the nine observation wclls installed for this study. The tests were done using the method described by Bouwer and Rice (1976) and Bouwer (1989). The results of these tests were used with the results of slug tests and pumping tests conducted by other investigators to estimate velocity of groundwater flow. 


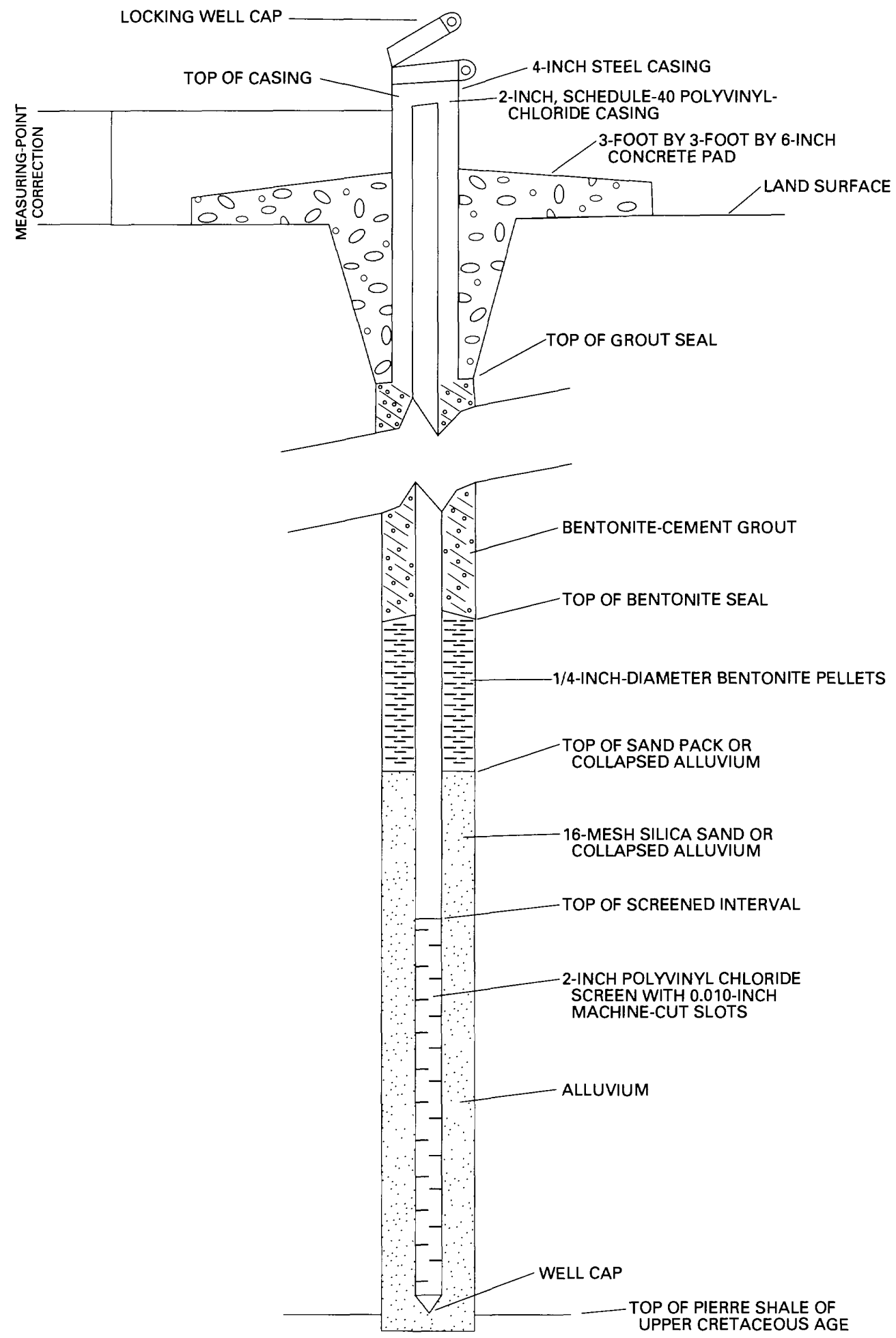

Flgure 2. Generalized well construction of observation wells installed for this study. 


\section{HYDROGEOLOGY OF ALLUVIAL AQUIFERS}

The PUDA is underlain by two alluvial aquifers: (1) The terrace alluvial aquifer, which is a southernmost, downgradient part of an erosional remnant of an extensive terrace deposit, which underlies almost three-fourths of the facility; and (2) the Chico Creek alluvial aquifer, a smaller system, which underlies about one-sixth of the facility along its western border. The relation between the terrace alluvial aquifer and the Chico Creek alluvial aquifer is illustrated in figure 3. The alluvium unconformably overlies the Pierre Shale of Upper Cretaceous age, an almost impermeable bedrock unit. The Pierre Shale consists of thinly bedded, dark gray to black shale and sandy shale; dips slightly to the north-northeast; and is about $1,200 \mathrm{ft}$ thick in the vicinity of the PUDA (Watts and Ortiz, 1990, p. 13). The uppermost major waterbearing formation beneath the alluvial aquifers is the Dakota Sandstone of Lower Cretaceous age, which is about 2,200 $\mathrm{ft}$ or more beneath the land surface at the PUDA (Robson and Banta, 1987).

\section{Description of Aquifers}

The alluvium primarily consists of sand separated by clay layers (table 3 in the "Supplemental Data" section). The bedrock surface underlying the terrace alluvial aquifer and the Chico Creek alluvial aquifer is irregular because of erosion prior to deposition of the alluvium. Consequently, thickness of the alluvium varies considerably. The boundaries of an alluvial aquifer are defined as the line of zero saturated thickness, which primarily is controlled by the altitude of the water table and the configuration of the underlying bedrock surface.

\section{Terrace Alluvial Aquifer}

The configuration of the bedrock surface underlying the terrace alluvial aquifer is shown on plate 1 . Downcutting by Chico Creek formed the western boundary of the terrace deposits. Between this boundary and the eastern boundary of the Chico Creek alluvial aquifer is a relatively steep scarp consisting of reworked terrace deposits, colluvium, soil, and, locally, eolian silt. The virtual absence of exposed bedrock and the scarcity of drill-hole data made the aquifer boundaries along these scarps difficult to define accurately. The southernmost boundary of the terrace deposits is formed by a similar scarp caused by the downcutting of the Arkansas River Valley. In sections 33 and 34 of Township 20 South, Range 62 West (see "System of Numbering Wells" in the "Supplemental Data" section), exposed alluvium-bedrock contacts and the presence of contact springs enable relatively accurate definition of the terrace-aquifer boundary. Downcutting by Boone Creek has removed a large section of the terrace alluvium for a distance extending about $3 \mathrm{mi}$ north of the Arkansas River Valley, causing separation of the terrace alluvial aquifer into two hy'drologically distinct areas. Downcutting by Boone Creek onto a southeast-trending bedrock ridge has caused removal of terrace alluvium, forming an alluvial "window" about $0.5 \mathrm{mi}$ long, which is headed by a bedrockcontact spring in the southwest quarter of section 11 , Township 20 South, Range 62 West (pl. 1). Downcutting by Haynes Creek has formed the eastern boundary of the terrace alluvial aquifer. No spring: or seeps have been observed to flow in the terrace deposits along this boundary. Because of the lack of bedrock outcrops and drill-hole data, the location of this aquif $r$ boundary was inferred primarily on the basis of topography, as was most of the aquifer boundary east and west of Boone Creek. The terrace alluvial aquifer extends for tens of miles north of the PUDA.

Drillers' logs for wells drilled for this study (table 3 in the "Supplemental Data" section) and previous USGS studies (Welder and Hurr, 1971; Watts and Ortiz, 1990) indicate that the terrace alluvium generally consists of 1 to $10 \mathrm{ft}$ of sandy or silty clay, clayey or sandy silt, or clayey or silty fine- to mediumgrained sand underlain by interbedded layers of poorly sorted, often clayey and gravelly, fine- to coarsegrained sand. Some logs indicated occasional sandy clay layers, which are generally 1 to $4 \mathrm{ft}$ thick, separating sand layers. The seven holes drilled in terrace alluvium for this study penetrated 40.6 to $94.8 \mathrm{ft}$ of alluvium.

The Pierre Shale was eroded by th: ancient river that deposited the terrace alluvium. The surface of the Pierre Shale (pl. 1) generally slopes to the southsoutheast from an altitude of about $\left.4,76^{\circ}\right) \mathrm{ft}$ near the northwestern corner of the PUDA to about $4,580 \mathrm{ft}$ in the southeastern corner; the average slope is about $28 \mathrm{ft} / \mathrm{mi}$. The bedrock surface is relatively regular beneath the northern two-thirds of the trrace deposits beneath the PUDA, except for an arcuate trough trending south-southwest across the terrace from the northeastern corner of the terrace deposits (pl. 1). This trough is a paleochannel cut by an ancient river during deposition of terrace alluvium. Four major water-supply wells were emplaced in this trough near the northern end of the facility. 


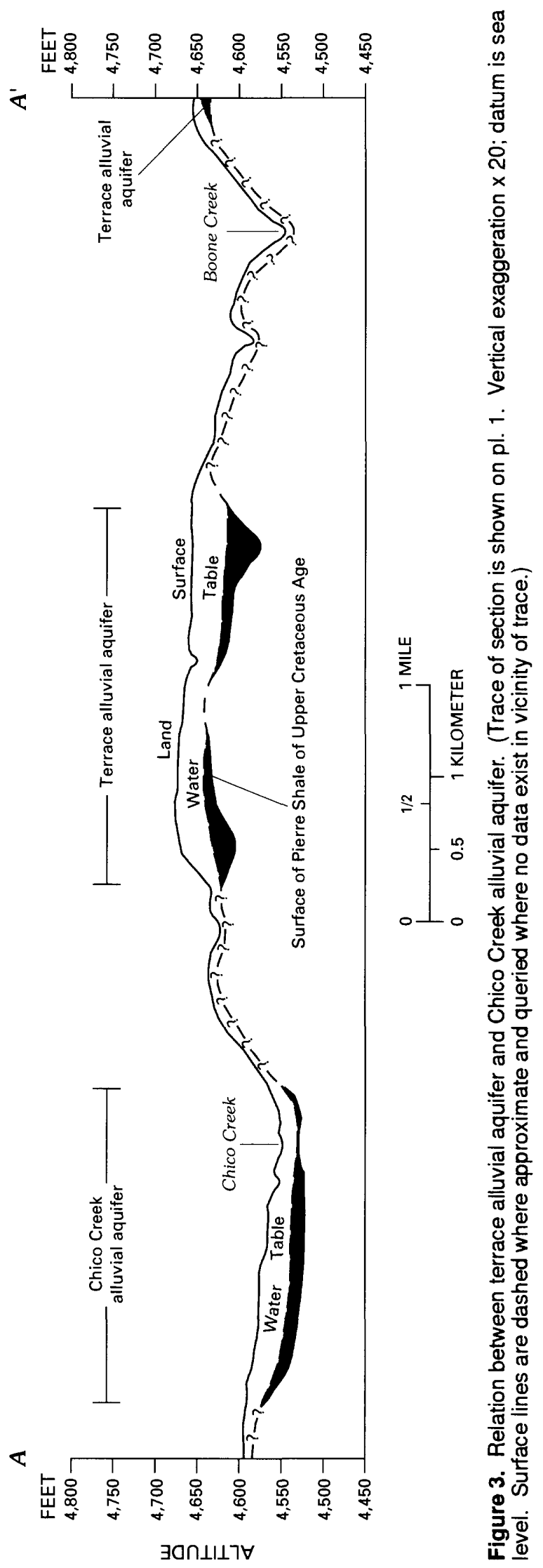


The bedrock beneath the southwestern part of the terrace aquifer forms an irregular surface of troughs, hills, and ridges, probably because of geomorphic processes associated with the migrating confluence of the ancestral Arkansas River with the ancestral tributary river that deposited the terrace alluvium. The bedrock configuration east of Boone Creek is not well defined because of a scarcity of bedrock-altitude data.

Saturated thickness (pl. 2) at a point in alluvium is determined by subtracting the bedrock altitude (pl. 1) from the altitude of the water table (pl. 3). The saturated thickness of the terrace alluvial aquifer (pl. 2) varied from 0 to about $45 \mathrm{ft}$. Generally, saturated thickness was greatest along the previously described bedrock paleochannel near the northern boundary of the PUDA and decreases along the paleochannel to the south and away from it to the east and west. In the administration area, saturated thickness (pl. 2) varied irregularly from 0 to about $40 \mathrm{ft}$, largely reflecting the configuration of the bedrock surface. In the southeastern quarter of section 28 , Township 20 South, Range 62 West, an area of higher bedrock has caused alluvium to be unsaturated locally. Insufficient drillhole data exist to allow accurate definition of the distribution of saturated thickness in the terrace alluvial aquifer east of Boone Creek; existing data at one well indicates a saturated thickness of $37 \mathrm{ft}$ near the southeastern corner of the PUDA.

\section{Chico Creek Alluvial Aquifer}

The configuration of the bedrock surface underlying the Chico Creek alluvial aquifer is shown on plate 1. The presence of colluvium and eolian deposits overlapping the alluvium and the scarcity of drill-hole data made delineation of the boundaries of the Chico Creek alluvial aquifer more tentative than the delineation of the boundaries of the terrace alluvial aquifer. The boundaries shown for the Chico Creek alluvial aquifer on plate 1 are approximated from field observations of topography and relatively scarce drill-hole data. Data were most abundant along the northernmost $2 \mathrm{mi}$ of the eastern boundary. Of particular interest is the presence of unsaturated alluvium across the alluvial valley near the northern boundary of the PUDA, as determined during the drilling of two dry test holes (ODSB-01 and ODSB-02, pl. 1) for this study. An observation well that was drilled by Engineering Science, Inc., $0.2 \mathrm{mi}$ to the east-southeast of ODSB-02 indicated about $0.5 \mathrm{ft}$ of water over bedrock; this water possibly represents discharge of terrace water through colluvium along the northern border of the PUDA, as is indicated by the presence of an isolated cluster of cottonwood trees and brush along the scarp. The most likely area for inflow of water in the Chico Creek alluvial aquifer is near Chico Creek along the western boundary of the aquifer. Additional data are needed to more fully define the ground-water-inflow area. The bedrock-surface altitude along Chico Creek decreases from about $4,700 \mathrm{ft}$ at the northern border of the PUDA to about 4,500 ft where the Chico Creek alluvium grades into the Arkansas River Valley (pl. 1), resulting in an average bedrock-surface slope of at)ut $31 \mathrm{ft} / \mathrm{mi}$. Data were insufficient to define accurately any detailed variations (such as channels) in the bedrock surface.

Drillers' logs for wells drilled in the Chico Creek alluvium by the USGS and Engineering Science, Inc., indicate that the alluvium generally consists of 2 to $7 \mathrm{ft}$ of sandy silt (or local clay) underlain by poorly sorted sandy gravel and gravelly sand (often with clay), locally interbedded with thin layers of sandy clay or sandy silt (table 3 in the "Supplemental Data" section). Saturated thickness of the Chico Creek all:ıvium ranges from 0 to about $30 \mathrm{ft}$, but generally is less than $15 \mathrm{ft}$ (pl. 2). Total thickness of the Chico Creek alluvium in the saturated area ranges from 16 to $41 \mathrm{f}$.

\section{Directions and Velocities of Ground-Water Flow}

Direction of water flow in the alluvial aquifers at the PUDA generally is from north to south (pl. 3). Flow direction was determined from a map of the water-table altitude (pl. 3); generally, the direction of ground-water flow was perpendicular to contours of equal water-table altitude and from higher to lower altitudes. However, the water-table contours on plate 3 need to be used with caution when determining flow direction in areas where data are sparse, contours are irregular, or flow direction is affected by drainage along the boundaries of the alluvial aquifers.

Vertically averaged velocity of water flow in the unconfined alluvial aquifers can be estimated by the equation:

$$
\mathrm{V}=\mathrm{KI} / \phi \text {, }
$$

where

$$
\begin{aligned}
& \mathrm{V}=\text { average ground-water velocity, } \\
& \mathrm{K}=\text { hydraulic conductivity, } \\
& \mathrm{I}=\text { hydraulic gradient, and } \\
& \phi \quad=\text { porosity. }
\end{aligned}
$$


Estimates of velocity derived from this equation are averages based on the screened intervals of observation wells in which hydraulic conductivity was measured. In a screened interval, water flows more slowly in less permeable layers and more rapidly in more permeable layers compared to the average velocity. Similarly, hydraulic conductivity can vary considerably over relatively small horizontal distances, reflecting the small-scale heterogeneity of the alluvial aquifers. Additionally, the bail tests used to measure hydraulic conductivity are substantially limited in accuracy and cause additional uncertainty in the estimates of velocity. Because of the limitations inherent in estimating ground-water-flow velocity, these velocities need to be used with some caution when attempting to determine velocity of contaminant migration, especially because contaminants may migrate through thin, permeable layers many times more rapidly than the average ground-water velocity would indicate. This section describes direction and velocity of groundwater flow in the terrace and Chico Creek alluvial aquifers.

\section{Terrace Alluvial Aquifer}

The direction of water flow in the terrace alluvial aquifer at the PUDA (pl. 3) generally is southward. The direction of flow is due south in the northern one-half of the PUDA, except near Haynes Creek, where flow directions to the east-southeast, southeast, and east indicate subsurface discharge through colluvium to Haynes Creek. In the southwestern part of the terrace alluvial aquifer, flow direction varies in a complex pattern between west, south, and east in response to the effects of drainage off the terrace and, to a much smaller extent, pumpage from water-supply wells. Flow directions to the east and southeast toward the aquifer boundary west of Boone Creek indicate subsurface discharge through colluvium to Boone Creek. Along the southwestern terrace-aquifer boundary, prominent subsurface-discharge zones are present in the southern half of section 20 and the northern half of section 32 of Township 20 South, Range 62 West. In the southeastern quarter of section 33 and the southwestern quarter of section 34 of this township, numerous springs and seeps discharge into a colluvial ravine that drains southward to the Arkansas River alluvial aquifer. East of Boone Creek, water in the terrace aquifer generally flows to the southeast and into colluvium bordering Haynes Creek and Boone Creek.
Estimates for vertically averaged velocity of water flow in the terrace alluvial aquifer vary cc nsiderably, mostly because of differences in measured hydraulic conductivity. Values of hydraulic conductivity (table 1, fig. 4) range from 0.4 to $400 \mathrm{ft} / \mathrm{d}$ : the median value is $26 \mathrm{ft} / \mathrm{d}$. Estimates of hydraulic gradient range from 0.003 to almost 0.02 ; estimates of 0.01 to almost 0.02 represented discharge areas in the southwestern part of the aquifer; an estimate of abou 0.006 was typical for most of this aquifer. Velocity of ground-water flow was estimated for most of the areas and all of the solitary wells shown in figure 4 . These estimates are based on an assumed porosity of 0.2 and range from 0.02 to $3 \mathrm{ft} / \mathrm{d}$ (pl. 3); the median velocity was $0.8 \mathrm{ft} / \mathrm{d}$ (for 17 values). Velocity was not estimated for areas 3, 7, and 10 in figure 4 because of complex patterns of flow paths and the substantial variat in in hydraulic conductivity in these areas. However, local, small-scale flow velocity may be as large as $8 \mathrm{f}^{+} / \mathrm{d}$ in area 3 and $11 \mathrm{ft} / \mathrm{d}$ in area 10 (fig. 4).

The rate of ground-water inflow into the PUDA through the terrace alluvial aquifer can be estimated by the following equation:

$$
\mathrm{Q}=\mathrm{KIA} \text {, }
$$

where

$\mathrm{Q}=$ average volume of discharge,

$\mathrm{K}=$ hydraulic conductivity,

$\mathrm{I}=$ hydraulic gradient, and

$\mathrm{A}=$ cross-sectional area of saturated allu'

Along the northern border of the PUDA, the terrace aquifer is about $16,000 \mathrm{ft}$ wide where the water-table contours are approximately parallel to the northern border (pl. 3) and is estimated to average $25 \mathrm{ft}$ in saturated thickness (pl. 2). Using these values, an average hydraulic conductivity of $26 \mathrm{ft} / \mathrm{d}$ (the median value of terrace deposits), and an estimated average hydaulic gradient of 0.0045 , results in an inflow rate of ahout $47,000 \mathrm{ft}^{3} / \mathrm{d}$ (1.1 acre-ft/d). Assuming negligib'e recharge to the terrace aquifer at the PUDA, thic estimate also applies to total outflow from the terrace aquifer beneath the PUDA from discharge to springs and into colluvium, ground-water withdrawals, and outflow through the terrace aquifer along the southern boundary of the PUDA east of Boone Creek. Most of the uncertainty in the accuracy of this estimate results from uncertainty in the average hydraulin. conductivity. 
Table 1. Values of hydraulic conductivity of the alluvial aquifers at the Pueblo Depot Activity

[Areas and solitary wells are shown in figure 4]

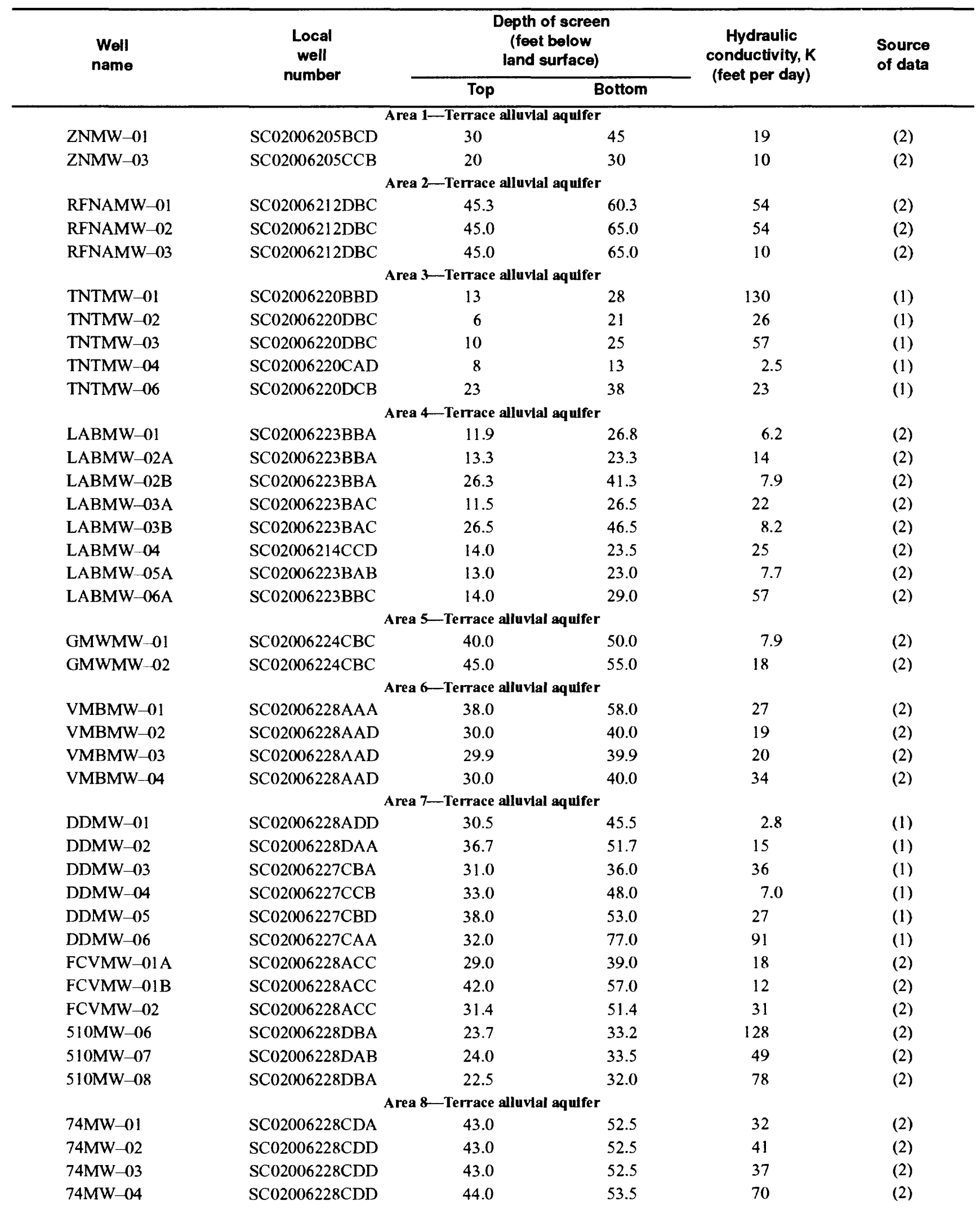


Table 1. Values of hydraulic conductivity of the alluvial aquifers at the Pueblo Depot Activity--Continued

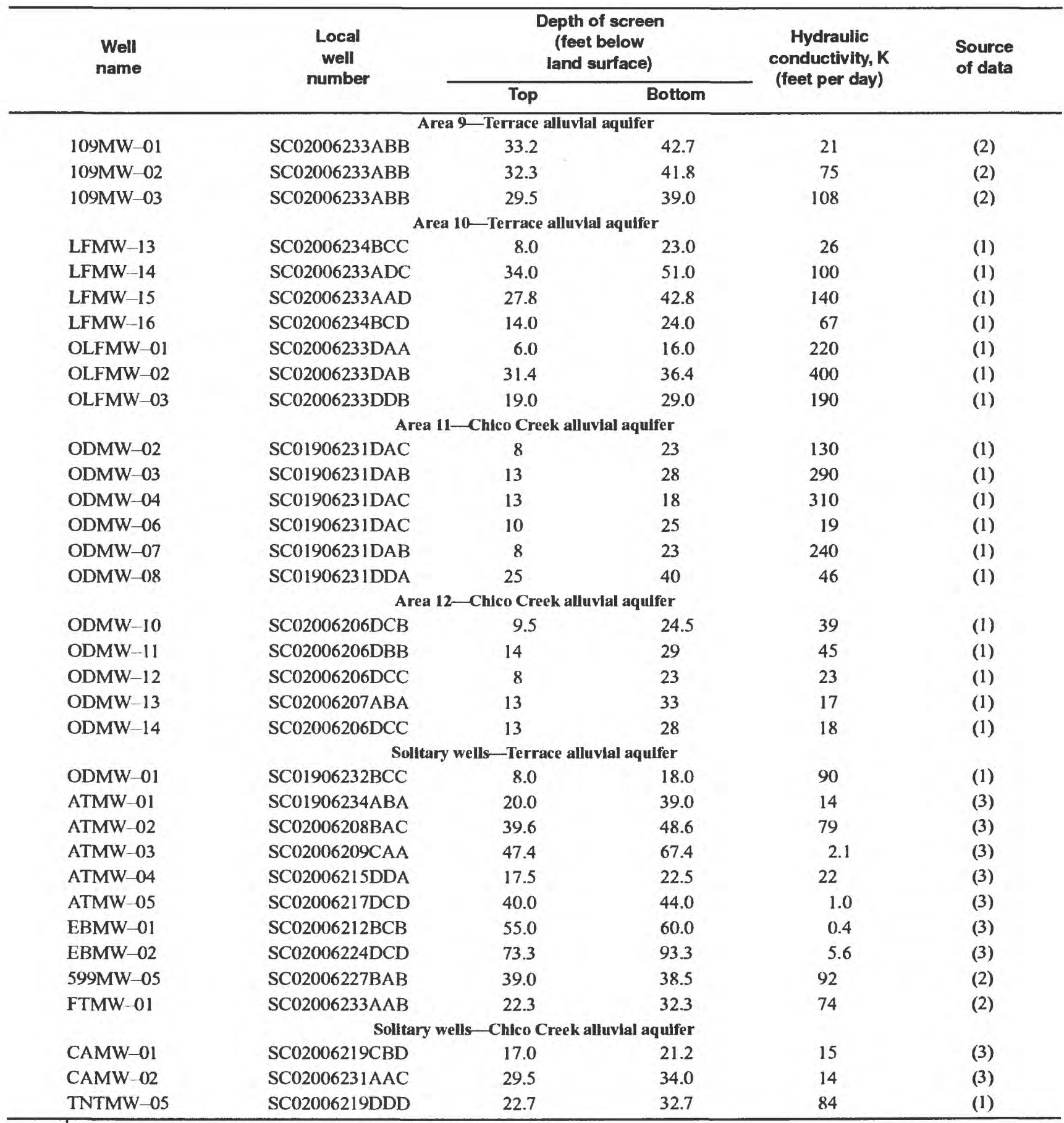

'Daniel Brookshire, Engineering-Science, Inc., written commun., 1990.

${ }^{2}$ Theresa Shock, Black \& Veatch Waste Science and Technology Corp., written commun., 1994.

${ }^{3}$ U.S. Geological Survey, data collected for this study, 1993. 


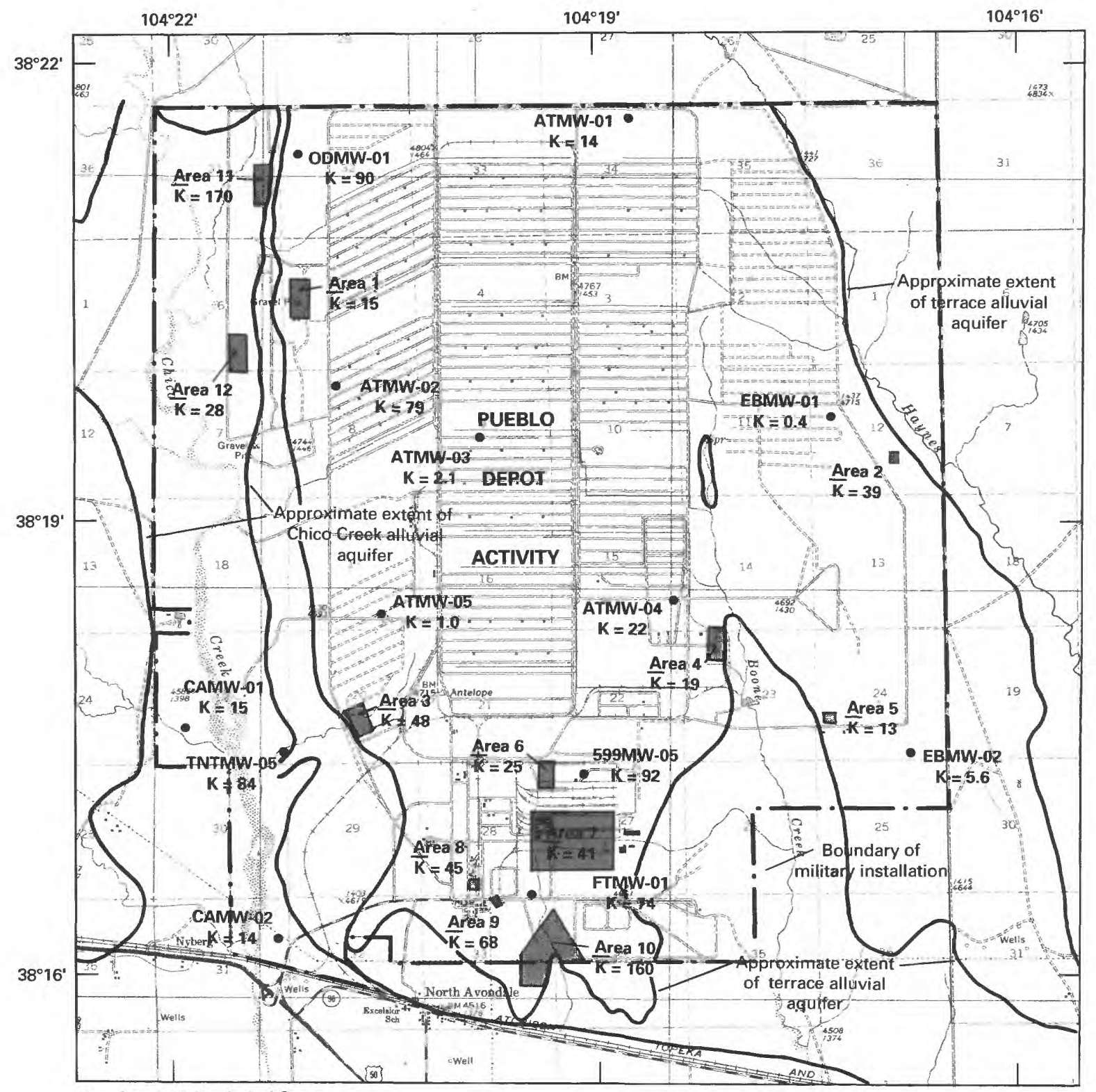

Base from U.S. Geological Survey

Pueblo County, 1:50,000, 1975

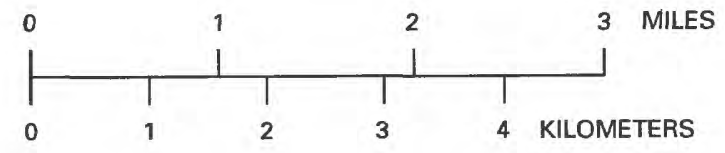

\section{EXPLANATION}

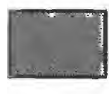

Area 9

AREA OF MULTIPLE AQUIFER TESTS-Shows

$\bar{K}=68$ average hydraulic conductivity, $\bar{K}$, in feet per

day. Refer to table 1 for individual values

- FTMW-01 LOCATION OF OBSERVATION WELL-Shows

$K=74$ name of well and hydraulic conductivity, $K$, in

feet per day. Refer to table 1 for individual values

Figure 4. Values of hydraulic conductivity of the alluvial aquifers at the Pueblo Depot Activity. 


\section{Chico Creek Alluvial Aquifer}

The direction of water flow in the Chico Creek alluvial aquifer at the PUDA (pl. 3) generally is southward to the Arkansas River alluvial aquifer. Exceptions are where ground-water inflow along the margins of the aquifer causes flow to the southwest along the eastern margin and flow to the southeast along the western margin of the aquifer.

Estimates for vertically averaged velocity of water flow in the Chico Creek alluvial aquifer range from 0.5 to $4 \mathrm{ft} / \mathrm{d}$ (pl. 3). These estimates are based on measured hydraulic conductivity between 14 and $310 \mathrm{ft} / \mathrm{d}$ (table 1) (median $42 \mathrm{ft} / \mathrm{d}$ ), estimated hydraulic gradient of 0.005 to 0.007 , and an assumed porosity of 0.2 . The area of greatest flow velocity is near the northern boundary of the PUDA along the eastern boundary of the Chico Creek aquifer (area 11 in fig. 4). Here, local small-scale flow velocities may be as large as $8 \mathrm{ft} / \mathrm{d}$.

The volume of water discharging from the Chico Creek alluvial aquifer into the Arkansas River alluvial aquifer can be estimated by equation 2 . Along the northern boundary of section 31 of Township 20 South, Range 62 West, the aquifer is about $5,300 \mathrm{ft}$ wide and is estimated to average $15 \mathrm{ft}$ in saturated thickness (pl. 2). Using these values, an average hydraulic conductivity of $14 \mathrm{ft} / \mathrm{d}$ (the value for well CAMW-02 in fig. 4), and an average hydraulic gradient of 0.005 , results in a discharge rate of about $6,000 \mathrm{ft}^{3} / \mathrm{d}(0.14$ acre- $\mathrm{ft} / \mathrm{d})$.

\section{General Quality of Ground Water}

A detailed description of the quality of the ground water in the alluvial aquifers at the PUDA is beyond the scope of this report; however, a discussion of specific conductance as an indicator of dissolvedsolids concentration is included to characterize general water quality. The distribution of specific conductance is shown on plate 4 .

\section{Terrace Alluvial Aquifer}

Specific conductance of water in the terrace alluvial aquifer generally was less than $800 \mu \mathrm{S} / \mathrm{cm}$. The smallest values were in the north-central part of the PUDA. The values increased slightly to the south and toward the eastern and western boundaries of the aquifer. In the southwestern part of the terrace aquifer, values of specific conductance as large as $3,300 \mu \mathrm{S} / \mathrm{cm}$ were measured locally, and irregular variations in values made contouring of most data points impractical. These relatively large, variable values were the result of disposal of wastes at several sites, including a sanitary landfill in the northeastern quarter of section 33 of Township 20 South, Range 62 West (Watts and Ortiz, 1990). More detailed descriptins of these sites are beyond the scope of this study.

The analyses of water from 10 wells in the terrace alluvial aquifer, which are listed in table 4 (in the "Supplemental Data" section), indicate tl at dissolved-solids concentrations (as the sum of constituents) can be estimated by multiplying specificconductance values by factors between 0.59 and 0.65 (average 0.62). Therefore, most water in the terrace alluvial aquifer has dissolved-solids concentrations less than $500 \mathrm{mg} / \mathrm{L}$, except for water in the administrative area in the southwestern part of the aquifer. The analyses also indicate that most or all of the water in the terrace alluvial aquifer probably was dominated by the sodium cation and usually by the bicarbonate anion; sulfate usually was present in substantial (and, in some of the analyses, predominant) concentrations.

\section{Chico Creek Alluvial Aquifer}

Measured specific conductance of water in the Chico Creek alluvial aquifer (pl. 4) ranged from 683 to $1,460 \mu \mathrm{S} / \mathrm{cm}$. In the northern part of the study area along the eastern boundary of the Chico Creek alluvial aquifer, measured specific conductance varied between 683 and $1,380 \mu \mathrm{S} / \mathrm{cm}$.

The analyses of water from three wells in the Chico Creek alluvial aquifer listed in table 4 indicate that dissolved-solids concentrations can be estimated by multiplying specific-conductance values by f ctors between 0.65 and 0.68 (average 0.67 ). Therefore, all measured specific conductance for water in the Chico Creek alluvial aquifer indicate dissolved-solids concentrations less than $1,000 \mathrm{mg} / \mathrm{L}$. These analyses also indicate that water in the Chico Creek alluvial aquifer was dominated by the sodium cation and by the bicarbonate and sulfate anions; sulfate was more predominant to the south.

\section{SUMMARY}

The Pueblo Depot Activity is underlain by two alluvial aquifers: (1) The terrace alluvial aquifer in an erosional remnant of an extensive terrace deposit, which underlies almost three-fourths of the facility; and (2) the Chico Creek alluvial aquifer in the alluvium of Chico Creek, a much smaller system, which underlies about one-sixth of the facility along its western border. Both alluvial aquifers are underlain by the Pierre Shale of Upper Cretaceous age, an almost impermeable unit. The alluvial aquifers largely consist of sand separated by clay layers. 
Seven holes drilled in the terrace alluvial aquifer for this study penetrated 40.6 to $94.8 \mathrm{ft}$ of alluvium. The surface of the underlying Pierre Shale generally slopes to the south-southeast, with an average slope of about $28 \mathrm{ft} / \mathrm{mi}$. The bedrock surface, which is relatively regular beneath the northern two-thirds of the terrace deposits, forms an irregular surface of troughs, hills, and ridges in the southwestern part of the terrace alluvial aquifer. The saturated thickness of the terrace alluvial aquifer varied from 0 to about $45 \mathrm{ft}$.

The Pierre Shale surface beneath the Chico Creek alluvial aquifer generally slopes to the south, with an average slope of about $31 \mathrm{ft} / \mathrm{mi}$. Saturated thickness of the Chico Creek alluvium ranges from 0 to about $30 \mathrm{ft}$, but generally is less than $15 \mathrm{ft}$. Total thickness of the Chico Creek alluvium in the saturated area ranges from 16 to $41 \mathrm{ft}$.

The direction of water flow in the terrace alluvial aquifer generally is southward. In the southwestern part of the terrace alluvial aquifer, flow directions vary complexly. Estimates for velocity of ground-water flow vary considerably, mostly because of differences in measured hydraulic conductivity, which ranged from 0.4 to $400 \mathrm{ft} / \mathrm{d}$ (median $26 \mathrm{ft} / \mathrm{d}$ ), but also because of differences in hydraulic gradient, which ranged from 0.003 to almost 0.02 . Estimates for vertically averaged ground-water-flow velocity ranged from 0.02 to $3 \mathrm{ft} / \mathrm{d}$ (median $0.9 \mathrm{ft} / \mathrm{d}$ ).

The direction of ground-water flow in the Chico Creek alluvial aquifer generally is southward to the Arkansas River alluvial aquifer, except near the margins of the aquifer. Estimates for vertically averaged ground-water flow velocity ranged from 0.5 to $4 \mathrm{ft} / \mathrm{d}$ (median $0.7 \mathrm{ft} / \mathrm{d}$ ) based on measured values of hydraulic conductivity between 14 and $310 \mathrm{ft} / \mathrm{d}$ (median $42 \mathrm{ft} / \mathrm{d}$ ), estimated hydraulic gradients of 0.005 to 0.007 , and an assumed porosity of 0.2 . The rate of ground-water flow from the Chico Creek alluvial aquifer into the Arkansas River alluvial aquifer was estimated to be about $6,000 \mathrm{ft}^{3} / \mathrm{d}(0.14 \mathrm{acre}-\mathrm{ft} / \mathrm{d})$.

Specific conductance of water in the terrace alluvial aquifer generally was less than $800 \mu \mathrm{S} / \mathrm{cm}$, and the smallest values were in the north-central part of the PUDA. In the southwestern part of the terrace alluvial aquifer, values of specific conductance as large as $3,300 \mu \mathrm{S} / \mathrm{cm}$ were measured locally and varied irregularly. Dissolved-solids concentrations can be estimated by multiplying the specific-conductance values by fac- tors between 0.59 and 0.65 (average 0.62 ), indicating that ground water in the terrace alluvial aquifer generally had dissolved-solids concentrations less than $500 \mathrm{mg} / \mathrm{L}$, except for the administrative area in the southwestern part of the terrace alluvial aquifer. Waterquality analyses indicate that this water was dominated by the sodium cation and that the major anion usually was bicarbonate; sulfate usually was present in substantial (and sometimes predominant) concentrations.

Measured specific conductance of water in the Chico Creek alluvial aquifer ranged from 683 to $1,460 \mu \mathrm{S} / \mathrm{cm}$. Dissolved-solids concentrations can be estimated by multiplying specific-conductance values by factors between 0.65 and 0.68 (average 0.67 ), indicating dissolved-solids concentrations were less than $1,000 \mathrm{mg} / \mathrm{L}$. Water-quality analyses indicated dominance by the sodium cation and the bicarbonate and sulfate anions; sulfate was more predominant to the south.

\section{REFERENCES CITED}

Bouwer, Herman, 1989, The Bouwer and Rice slug testAn update: Groundwater, v. 27, no. 3, p. 304-309.

Bouwer, Herman, and Rice, R.C., 1976, A slug test for determining hydraulic conductivity of unconfined aquifers with completely or partially penetrating wells: Water Resources Research, v. 12, no. 3, p. 423-428.

Nelson, G.A., Hurr, R.T., and Moore, J.E., 1989, Hydrogeologic characteristics of the valley-fill aquifer in the Arkansas River Valley, Pueblo County, Colorado: U.S. Geological Survey Open-File Rerort 89-256, 3 sheets, scale 1:62,500.

Robson, S.G., and Banta, E.R., 1987, Geology and hydrology of deep bedrock aquifers in eastern Colorado: U.S. Geological Survey Water-Resources Investigations Report 85-4240, 6 sheets, scale 1:500,000.

Watts, K.R., and Ortiz, R.F., 1990, Geohydrology and ground-water quality at the Pueblo Deprt Activity landfill near Pueblo, Colorado: U.S. Geological Survey Water-Resources Investigations Repor ${ }^{\circ}$ 89-4143, 75 p.

Welder, F.A., and Hurr, R.T., 1971, Apprais 1 of shallow ground-water resources, Pueblo Army Depot, Colorado: U.S. Geological Survey Op?n-File Report 71006, 44 p. [Available from Earth Science Information Center, Open-File Reports Section, Box 25286, MS 517, Denver Federal Center, Denver, CO 80225 as Open-File Report 72-447.] 
SUPPLEMENTAL DATA 


\section{System of Numbering Wells}

The locations of wells and test holes in this report are given numbers based on the Bureau of Land Management system of land subdivision and show the location of the well by quadrant, township, range, section, and position within the section. The first letter "S" preceding the location number indicates that the well or test hole is located in the area governed by the Sixth Principal Meridian. The second letter indicates the quadrant in which the well or test hole is located. Four quadrants are formed by the intersection of the baselin? and the principal meridian: A indicates the northeast quadrant, $B$ the northwest, $C$ the southwest, and $D$ the southeast.

The first three digits of the number indicate the township, the next three digits the range, anc the last two digits the section in which the well or test hole is located. The letters following the section number locate the well or test hole within the section. The first letter denotes the quarter section, the second the quarter-q $\operatorname{larter}$ section, and the third the quarter-quarter-quarter section. The letters are assigned in a counterclockwise direction, beginning with $A$ in the northeast section and within each quarter-quarter and quarter-quarter-quarter section in the same manner. The letter " $X$ " indicates that the well or test hole is centered in the smallest quadrant subdivision listed. 


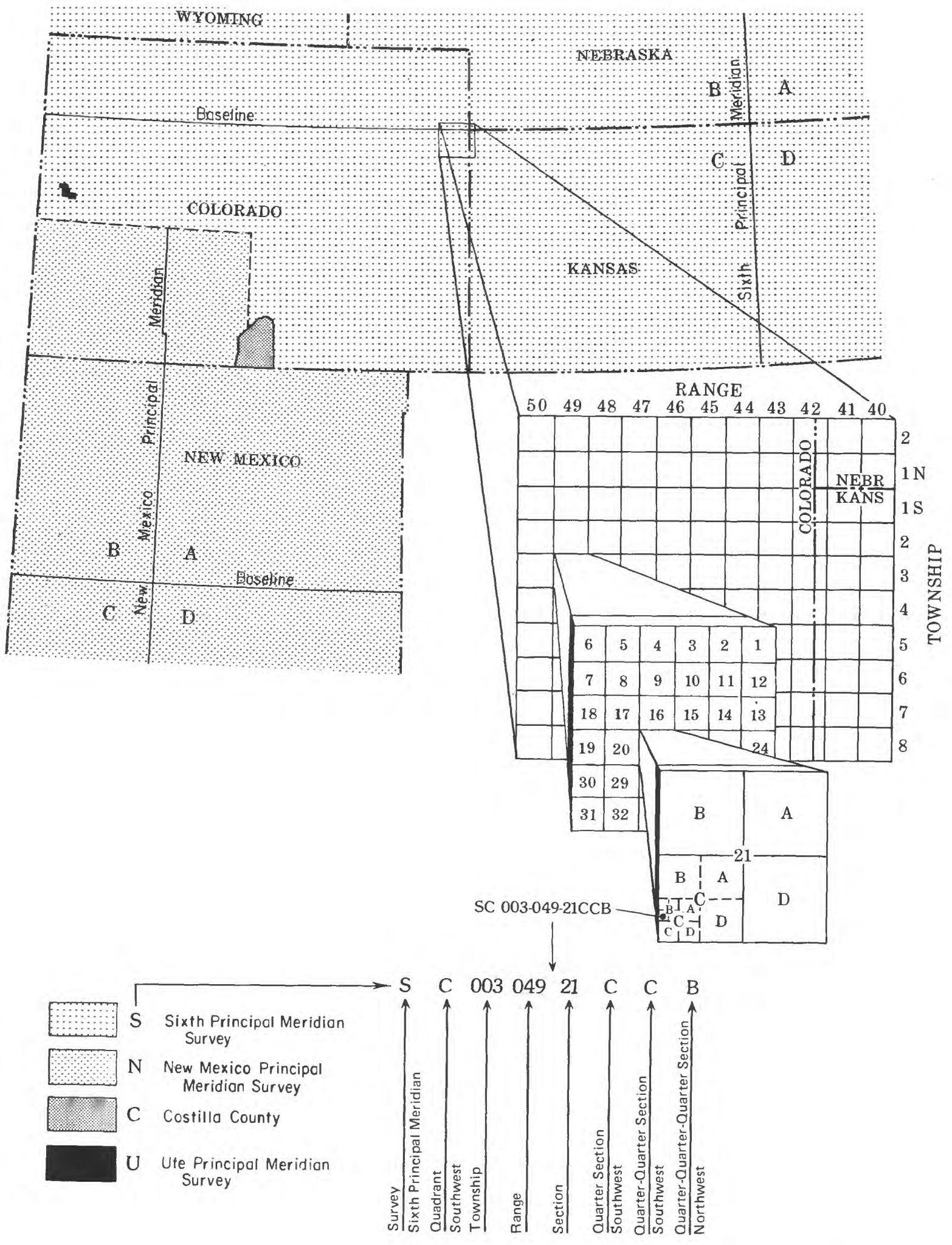


Table 2. Construction data for observation wells installed for this study

[See plate 1 for locations of observation wells]

\begin{tabular}{ccccccc}
\hline $\begin{array}{c}\text { Well } \\
\text { name }\end{array}$ & $\begin{array}{c}\text { Station } \\
\text { number }\end{array}$ & $\begin{array}{c}\text { Local } \\
\text { well } \\
\text { number }\end{array}$ & $\begin{array}{c}\text { Land- } \\
\text { surface } \\
\text { altitude } \\
\text { (feet) }\end{array}$ & $\begin{array}{c}\text { Top of casing } \\
\text { stick-up } \\
\text { height } \\
\text { (feet) }\end{array}$ & $\begin{array}{c}\text { Depth of screen } \\
\text { (feet below } \\
\text { land surface) }\end{array}$ \\
\hline ATMW-01 & 382138104191001 & SC01906234ABA & $4,782.9$ & 2.9 & 20.0 & 39.0 \\
ATMW-02 & 381949104214001 & SC02006208BAC & $4,759.1$ & 2.8 & 39.6 & 48.6 \\
ATMW-03 & 382029104223001 & SC02006209CAA & $4,753.1$ & 2.6 & 47.4 & 67.4 \\
ATMW-04 & 381825104184601 & SC02006215DDA & $4,688.4$ & 3.0 & 17.5 & 22.5 \\
ATMW-05 & 381818104212001 & SC02006217DCD & $4,715.0$ & 2.4 & 40.0 & 44.0 \\
EBMW-01 & 381941104173101 & SC02006212BCB & $4,717.7$ & 2.3 & 55.0 & 60.0 \\
EBMW-02 & 381723104165101 & SC02006224DCD & $4,676.7$ & 2.6 & 73.3 & 93.3 \\
& & Chico Creek alluvial aquifer & & & \\
CAMW-01 & 381734104225101 & SC02006219CBD & $4,578.2$ & 2.4 & 17.0 & 21.2 \\
CAMW-02 & 381615104221101 & SC02006231AAC & $4,542.0$ & 2.8 & 29.5 & 34.0 \\
\hline
\end{tabular}

Table 3. Drillers' logs for observation wells and test holes drilled for this study

[See plate 1 for site locations; $\mathrm{ft}$, feet: --, no data]

\begin{tabular}{|c|c|c|c|c|c|}
\hline $\begin{array}{l}\text { Local } \\
\text { well } \\
\text { number }\end{array}$ & $\begin{array}{c}\text { Land- } \\
\text { surface } \\
\text { altitude } \\
\text { (feet) }\end{array}$ & $\begin{array}{l}\text { Date } \\
\text { drilled }\end{array}$ & Lithology & $\begin{array}{l}\text { Thickness } \\
\text { (feet) }\end{array}$ & $\begin{array}{l}\text { Depth } \\
\text { (foet) }\end{array}$ \\
\hline \multicolumn{6}{|c|}{ Observation well ATMW-01 } \\
\hline \multirow[t]{10}{*}{ SC01906234ABA } & $4,782.9$ & $01-25-93$ & Terrace alluvium: & & \\
\hline & & & Sand, clayey & 4.5 & 4.5 \\
\hline & & & Silt, clayey & 6.5 & 11.0 \\
\hline & & & Clay, sandy & 6.6 . & 17.6 \\
\hline & & & Sand, clayey & 4.9 & 22.5 \\
\hline & & & Sand, gravelly & 18.3 & 40.8 \\
\hline & & & Sand & 4.2 & 45.0 \\
\hline & & & Sand, clayey & 10.3 & 55.3 \\
\hline & & & Gravel, sandy & 3.2 & 58.5 \\
\hline & & & Pierre Shale & -- & 58.5 \\
\hline \multicolumn{6}{|c|}{ Observatiou well ATMW-02 } \\
\hline \multirow[t]{8}{*}{ SC02006208BAC } & $4,759.1$ & 02-01-93 & Terrace alluvium: & & \\
\hline & & & Clay, silty & 4.8 & 4.8 \\
\hline & & & Clay, sandy & 4.4 & 9.2 \\
\hline & & & Sand, clayey & 2.0 & 11.2 \\
\hline & & & Sand, gravelly and clayey & 4.2 & 15.4 \\
\hline & & & Sand, clayey & 18.6 & 34.0 \\
\hline & & & Sand, gravelly and clayey & 15.5 & 49.5 \\
\hline & & & Pierre Shale & -- & 49.5 \\
\hline
\end{tabular}


Table 3. Drillers' logs for observation wells and test holes drilled for this study--Continued

\begin{tabular}{|c|c|c|c|c|c|}
\hline $\begin{array}{c}\text { Local } \\
\text { well } \\
\text { number }\end{array}$ & $\begin{array}{l}\text { Land- } \\
\text { surface } \\
\text { altitude } \\
\text { (feet) }\end{array}$ & $\begin{array}{l}\text { Date } \\
\text { drilled }\end{array}$ & Lithology & $\begin{array}{c}\text { Thickness } \\
\text { (feet) }\end{array}$ & $\begin{array}{l}\text { Despth } \\
\text { (f } \sim t)\end{array}$ \\
\hline \multicolumn{6}{|c|}{ Observation well ATMW -03} \\
\hline \multirow[t]{10}{*}{ SC02006209CAA } & $4,753.1$ & $02-02-93$ & Terrace alluvium: & & \\
\hline & & & Clay, silty and sandy & 6.3 & 6.3 \\
\hline & & & Sand, clayey & 3.5 & 9.8 \\
\hline & & & Sand, gravelly and clayey & 3.1 & 12.9 \\
\hline & & & Sand & 20.8 & $\$ 3.7$ \\
\hline & & & Sand, clayey & 7.5 & 41.2 \\
\hline & & & Sand, gravelly and clayey & 4.5 & 45.7 \\
\hline & & & Clay, sandy & .4 & 46.1 \\
\hline & & & Sand, clayey and silty & 21.9 & 68.0 \\
\hline & & & Pierre Shale & 1.0 & 69.0 \\
\hline \multicolumn{6}{|c|}{ Observation well ATMW-04 } \\
\hline \multirow[t]{10}{*}{ SC02006215DDA } & $4,688.4$ & $01-26-93$ & Terrace alluvium: & & \\
\hline & & & Clay, sandy & 2.3 & 2.3 \\
\hline & & & Sand, clayey & 2.4 & 4.7 \\
\hline & & & Clay, silty and sandy & 6.2 & 10.9 \\
\hline & & & Sand, clayey & 7.5 & 18.4 \\
\hline & & & Sand, gravelly & 6.5 & 24.9 \\
\hline & & & Clay, silty and sandy & 5.1 & 30.0 \\
\hline & & & Sand, clayey & 2.0 & 32.0 \\
\hline & & & Sand & 8.6 & 40.6 \\
\hline & & & Pierre Shale & -- & 40.6 \\
\hline \multicolumn{6}{|c|}{ Obserrvation well ATMW-05 } \\
\hline \multirow[t]{10}{*}{ SC02006217DCD } & $4,715.0$ & $01-27-93$ & Terrace alluvium: & & \\
\hline & & & Clay, sandy and silty & 8.8 & 8.8 \\
\hline & & & Sand, gravelly & 6.0 & 14.8 \\
\hline & & & Sand & 7.4 & 22.2 \\
\hline & & & Sand, gravelly & 12.9 & 35.1 \\
\hline & & & Clay, sandy & 4.0 & 39.1 \\
\hline & & & Sand & 5.8 & 44.9 \\
\hline & & & Sand, clayey & 5.3 & 50.2 \\
\hline & & & Sand & 3.3 & 53.5 \\
\hline & & & Pierre Shale & -- & 53.5 \\
\hline \multicolumn{6}{|c|}{ Observation well EBMW-01 } \\
\hline \multirow[t]{8}{*}{$\mathrm{SC} 02006212 \mathrm{BCB}$} & $4,717.7$ & $02-05-93$ & Terrace alluvium: & & \\
\hline & & & Clay, silty & 1.2 & 1.2 \\
\hline & & & Sand, clayey & 22.9 & 24.1 \\
\hline & & & Clay, sandy & 7.4 & 31.5 \\
\hline & & & Sand & 3.3 & 34.8 \\
\hline & & & Clay, gravelly and sandy & 24.4 & 59.2 \\
\hline & & & Sand, clayey & 1.0 & 60.2 \\
\hline & & & Pierre Shale & 1.3 & 61.5 \\
\hline
\end{tabular}


Table 3. Drillers' logs for observation wells and test holes drilled for this study--Continued

\begin{tabular}{|c|c|c|c|c|c|}
\hline $\begin{array}{c}\text { Local } \\
\text { well } \\
\text { number }\end{array}$ & $\begin{array}{l}\text { Land- } \\
\text { surface } \\
\text { altitude } \\
\text { (feet) }\end{array}$ & $\begin{array}{l}\text { Date } \\
\text { drilled }\end{array}$ & Llthology & $\begin{array}{c}\text { Thickness } \\
\text { (feet) }\end{array}$ & $\begin{array}{l}\text { Depth } \\
\text { (feet) }\end{array}$ \\
\hline \multicolumn{6}{|c|}{ Observation well EBMW-02 } \\
\hline \multirow[t]{12}{*}{ SC02006224DCD } & $4,676.7$ & $02-08-93$ & Terrace alluvium: & & \\
\hline & & & Clay, sandy & 8.6 & 8.6 \\
\hline & & & Sand, clayey & 14.4 & 23.0 \\
\hline & & & Sand & 27.0 & 50.0 \\
\hline & & & Gravel & .7 & 50.7 \\
\hline & & & Clay, sandy & 3.9 & 54.6 \\
\hline & & & Sand, clayey & 2.0 & 56.6 \\
\hline & & & Gravel and sand & 6.7 & 63.3 \\
\hline & & & Clay, sandy & 2.0 & 65.3 \\
\hline & & & Sand, clayey and gravelly & 9.3 & 74.6 \\
\hline & & & Sand & 20.2 & 94.8 \\
\hline & & & Pierre Shale & .2 & 95.0 \\
\hline \multicolumn{6}{|c|}{ Observation well CAMW-01 } \\
\hline \multirow[t]{8}{*}{ SC02006219CBD } & $4,578.2$ & $01-21-93$ & Chico Creek alluvium: & & \\
\hline & & & Silt, clayey & 9.0 & 9.0 \\
\hline & & & Sand, gravelly & 2.0 & 11.0 \\
\hline & & & Gravel & 1.5 & 12.5 \\
\hline & & & Sand, gravelly & 1.0 & 13.5 \\
\hline & & & Clay, sandy & 1.5 & 15.0 \\
\hline & & & Gravel, clayey & 7.0 & 22.0 \\
\hline & & & Pierre Shale & .1 & 22.1 \\
\hline \multicolumn{6}{|c|}{ Observation well $\mathrm{CAMW}-02$} \\
\hline \multirow[t]{14}{*}{ SC02006231 AAC } & $4,542.0$ & $01-28-93$ & Chico Creek alluvium: & & \\
\hline & & & Clay, silty & .9 & .9 \\
\hline & & & Silt, clayey & 2.0 & 2.9 \\
\hline & & & Sand, clayey and gravelly & 3.5 & 6.4 \\
\hline & & & Gravel and sand & 2.0 & 8.4 \\
\hline & & & Sand, clayey & 2.5 & 10.9 \\
\hline & & & Clay & .6 & 11.5 \\
\hline & & & Sand, silty and clayey & 5.0 & 16.5 \\
\hline & & & Sand & 4.7 & 21.2 \\
\hline & & & Clay, silty & 7.8 & 29.0 \\
\hline & & & Sand, clayey & 5.9 & 34.9 \\
\hline & & & Clay & 2.6 & 37.5 \\
\hline & & & Pierre Shale & -- & 37.5 \\
\hline & & & EBSB-01 & & \\
\hline \multirow[t]{3}{*}{ SC01906236ABD } & 4,770 & $02-04-93$ & Colluvium: & & \\
\hline & & & Clay, sandy (dry) & 5.9 & 5.9 \\
\hline & & & Pierre Shale & 8.5 & 14.4 \\
\hline
\end{tabular}


Table 3. Drillers' logs for observation wells and test holes drilled for this study--Continued

\begin{tabular}{|c|c|c|c|c|c|}
\hline $\begin{array}{l}\text { Local } \\
\text { well } \\
\text { number }\end{array}$ & $\begin{array}{l}\text { Land- } \\
\text { surface } \\
\text { altitude } \\
\text { (feot) }\end{array}$ & $\begin{array}{l}\text { Date } \\
\text { drilled }\end{array}$ & Lithology & $\begin{array}{c}\text { Thickness } \\
\text { (feet) }\end{array}$ & $\begin{array}{l}\text { Denth } \\
\text { (finet) }\end{array}$ \\
\hline \multicolumn{6}{|c|}{ Test hole EBSB-02 } \\
\hline \multirow{5}{*}{ SC02006226BX } & 4,632 & $01-29-93$ & Colluvium: & & \\
\hline & & & Clay, sandy (dry) & 5.0 & 5.0 \\
\hline & & & Pierre Shale & & \\
\hline & & & Shale, weathered, greyish-green & 2.2 & 7.2 \\
\hline & & & Siltstone, hard, red (dry) & .3 & 7.5 \\
\hline \multicolumn{6}{|c|}{ Test hole ODSB-01 } \\
\hline \multirow[t]{4}{*}{ SC01906231BAB } & 4,719 & $02-02-93$ & Chico Creek alluvium (dry): & & \\
\hline & & & Clay, silty & 3.3 & 3.3 \\
\hline & & & Sand, silty and gravelly & 14.1 & 17.4 \\
\hline & & & Pierre Shale & -. & 17.4 \\
\hline \multicolumn{6}{|c|}{ Test hole ODSB-02 } \\
\hline \multirow[t]{5}{*}{ SC01906231AAB } & 4,715 & $02-09-93$ & Chico Creek alluvium (dry): & & \\
\hline & & & Clay, sandy & 3.4 & 3.4 \\
\hline & & & Sand & 2.6 & 6.0 \\
\hline & & & Sand, gravelly & 13.6 & 19.6 \\
\hline & & & Pierre Shale & 2.4 & 22.0 \\
\hline
\end{tabular}

Table 4. Onsite measurements and concentrations of selected major inorganic constituents in samples collected from observation wells installed for this study and selected preexisting wells, June 1993

[ft, feet; $\mu \mathrm{S} / \mathrm{cm}$, microsiemens per centimeter at 25 degrees Celsius; ${ }^{\circ} \mathrm{C}$, degrees Celsius; <, less than; --, no data; IT, incremental titration; mg/L, milligrams per liter]

\begin{tabular}{|c|c|c|c|c|c|c|}
\hline $\begin{array}{c}\text { Well } \\
\text { name }\end{array}$ & $\begin{array}{c}\text { Local } \\
\text { well } \\
\text { number }\end{array}$ & $\begin{array}{c}\text { Date } \\
\text { sampled }\end{array}$ & $\begin{array}{c}\text { Water level, } \\
\text { depth below } \\
\text { land surface } \\
\text { (ft) }\end{array}$ & $\begin{array}{c}\text { Specific } \\
\text { conductance } \\
(\mu \mathrm{S} / \mathrm{cm})\end{array}$ & $\begin{array}{c}\text { PH } \\
\text { (standard } \\
\text { units) }\end{array}$ & $\begin{array}{c}\text { Temperature, } \\
\text { water } \\
{ }^{\circ} \mathrm{C} '\end{array}$ \\
\hline \multicolumn{7}{|c|}{ Terrace alluvial aquifer } \\
\hline ATMW-01 & SC01906234ABA & $06-22-93$ & 16.1 & 514 & 7.8 & $<13.5$ \\
\hline ATMW-02 & SC02006208BAC & $06-22-93$ & 40.5 & 640 & 7.5 & $<17.0$ \\
\hline ATMW-04 & SC02006215DDA & $06-21-93$ & 17.3 & 732 & 7.1 & $<22.5$ \\
\hline ATMW-05 & SC02006217DCD & $06-24-93$ & 35.7 & 647 & 8.1 & $<20.0$ \\
\hline EBMW-01 & SC02006212BCB & $06-24-93$ & 45.2 & 106 & 8.0 & $<17.0$ \\
\hline EBMW--02 & SC02006224DCD & $06-24-93$ & 67.4 & 690 & 8.0 & $<16.0$ \\
\hline TNTMW-01 & SC02006220BBD & $06-29-93$ & 25.8 & 757 & 7.8 & - \\
\hline \multicolumn{7}{|c|}{ Chico Creek alluvial aquifer } \\
\hline CAMW-01 & SC02006219CBD & $06-23-93$ & 15.3 & 119 & 7.7 & $<17.5$ \\
\hline CAMW-02 & SC02006231AAC & $06-22-93$ & 27.9 & 928 & 7.7 & $<19.0$ \\
\hline OBMW-05 & SC02006206ACD & $06-29-93$ & 23.6 & 761 & 7.8 & $<14.0$ \\
\hline
\end{tabular}


Table 4. Onsite measurements and concentrations of selected major inorganic constituents in samples collected from observation wells installed for this study and selected preexisting wells, June 1993--Continued

\begin{tabular}{|c|c|c|c|c|c|c|c|}
\hline $\begin{array}{l}\text { Well } \\
\text { name }\end{array}$ & $\begin{array}{l}\text { Alkalinity, } \\
\text { dissolved, } \\
\text { onsite, IT } \\
\text { (mg/L as } \\
\left.\mathrm{CaCO}_{3}\right)\end{array}$ & $\begin{array}{l}\text { Solids, } \\
\text { residue at } \\
180^{\circ} \mathrm{C}, \\
\text { dlssolved } \\
\text { (mg/L) }\end{array}$ & $\begin{array}{c}\text { Solids, } \\
\text { sum of } \\
\text { constituents, } \\
\text { dissolved } \\
\text { (mg/L) }\end{array}$ & $\begin{array}{c}\text { Calcium, } \\
\text { dissolved } \\
\text { (mg/L } \\
\text { as Ca) }\end{array}$ & $\begin{array}{c}\text { Magnesium, } \\
\text { dissolved } \\
\text { (mg/L } \\
\text { as Mg) }\end{array}$ & $\begin{array}{c}\text { Sodium, } \\
\text { dissolved } \\
\text { (mg/L } \\
\text { as } \mathrm{Na} \text { ) }\end{array}$ & $\begin{array}{c}\text { Potassium, } \\
\text { dissolved } \\
\text { (mg/L } \\
\text { as K) }\end{array}$ \\
\hline \multicolumn{8}{|c|}{ Terrace alluvial aquifer } \\
\hline ATMW-01 & 177 & 330 & 333 & 33 & 7.2 & 73 & 1.5 \\
\hline ATMW-02 & 125 & 418 & 407 & 38 & 8.9 & 87 & 2.6 \\
\hline ATMW-03 & 115 & 267 & 255 & 24 & 5.3 & 59 & 2.8 \\
\hline ATMW -04 & 174 & 481 & 460 & 47 & 10 & 100 & 1.0 \\
\hline ATMW-05 & 167 & 414 & 414 & 26 & 9.1 & 110 & 3.4 \\
\hline EBMW-01 & 252 & 692 & 671 & 17 & 6.3 & 210 & 1.6 \\
\hline EBMW-02 & 177 & 394 & 445 & 22 & 8.4 & 120 & 1.2 \\
\hline TNTMW-01 & 219 & 470 & 479 & 14 & 6.2 & 150 & 1.0 \\
\hline WS -02 & 104 & 333 & 304 & 33 & 7.6 & 69 & 1.7 \\
\hline WS -15 & 106 & 253 & 265 & 33 & 6.4 & 60 & 1.2 \\
\hline \multicolumn{8}{|c|}{ Chico Creek alluvial aquifer } \\
\hline CAMW-01 & 233 & 820 & 815 & 64 & 16 & 200 & 20.0 \\
\hline CAMW-02 & 171 & 575 & 608 & 60 & 14 & 130 & 4.5 \\
\hline OBMW-05 & 245 & 519 & 502 & 52 & 9.8 & 110 & 2.1 \\
\hline $\begin{array}{c}\text { Well } \\
\text { name }\end{array}$ & & & $\begin{array}{c}\text { Chloride, } \\
\text { dissolved } \\
\text { (mg/L } \\
\text { as CI) }\end{array}$ & $\begin{array}{c}\text { Fluorlde, } \\
\text { dissolved } \\
\text { (mg/L } \\
\text { as F) }\end{array}$ & \multicolumn{2}{|c|}{$\begin{array}{c}\text { Silica, } \\
\text { dissolved } \\
(\mathrm{mg} / \mathrm{L} \\
\left.\text { as } \mathrm{SiO}_{2}\right)\end{array}$} & $\begin{array}{c}\text { Nitrogen, } \\
\mathrm{NO}_{2}+\mathrm{NO}_{3} \text {, } \\
\text { dissolved } \\
(\mathrm{mg} / \mathrm{L} \\
\text { as } \mathrm{N})\end{array}$ \\
\hline \multicolumn{8}{|c|}{ Terrace alluvlal aquifer } \\
\hline ATMW-01 & \multicolumn{2}{|c|}{78} & 7 & 0.7 & \multicolumn{2}{|c|}{21} & 1.4 \\
\hline ATMW-02 & \multicolumn{2}{|c|}{150} & 15 & .5 & \multicolumn{2}{|c|}{21} & 2.2 \\
\hline ATMW-03 & \multicolumn{2}{|c|}{59} & 8 & .6 & \multicolumn{2}{|c|}{21} & 1.4 \\
\hline ATMW -04 & \multicolumn{2}{|c|}{140} & 29 & .7 & \multicolumn{2}{|c|}{27} & .35 \\
\hline ATMW-05 & \multicolumn{2}{|c|}{120} & 16 & 1.2 & \multicolumn{2}{|c|}{20} & 2.0 \\
\hline EBMW-01 & \multicolumn{2}{|c|}{250} & 21 & 3.1 & \multicolumn{2}{|c|}{11} & .19 \\
\hline EBMW-02 & \multicolumn{2}{|c|}{150} & 12 & .9 & \multicolumn{2}{|c|}{21} & .77 \\
\hline TNTMW_01 & \multicolumn{2}{|c|}{130} & 21 & 1.0 & \multicolumn{2}{|c|}{21} & .7 \\
\hline WS 02 & \multicolumn{2}{|c|}{84} & 14 & .5 & \multicolumn{2}{|c|}{23} & 2.2 \\
\hline WS -15 & \multicolumn{2}{|c|}{60} & 8 & .7 & \multicolumn{2}{|c|}{24} & 1.9 \\
\hline \multicolumn{8}{|c|}{ Chico Creek alluvial aquifer } \\
\hline CAMW-01 & \multicolumn{2}{|c|}{340} & 22 & .8 & \multicolumn{2}{|c|}{12} & .15 \\
\hline CAMW-02 & \multicolumn{2}{|c|}{260} & 15 & .7 & \multicolumn{2}{|c|}{15} & 1.5 \\
\hline OBMW-05 & & & 13 & .9 & & & 2.6 \\
\hline
\end{tabular}

